\title{
Electrochemical Determination of Cardiovascular Drug Cilnidipine at Glassy Carbon Electrode in Pharmaceutical Formulations
}

\author{
RAJ KUMAR SHARMA, MAHADEVA SINGH JAT, \\ K. K. JHANKAL and D K SHARMA*
}

Electrochemical Sensor Research Laboratory, Department of Chemistry, University of Rajasthan, Jaipur (Rajasthan)-302004, India sharmadkuor@gmail.com

Received 4 June 2019 / Accepted 3 July 2019

\begin{abstract}
Electrochemical behaviour of cilnidipine at glassy carbon electrode was investigated using cyclic, square wave cathodic adsorptive stripping (SW-CAdS) and differential pulse cathodic adsorptive stripping (DP-CAdS) voltammetry under different experimental conditions. The voltammetric peak current and potential for the reduction of cilnidipine were analysed at different $\mathrm{pH}$, scan rate and concentration. The voltammograms exhibited irreversible reduction of cilnidipine in $\mathrm{B} \mathrm{R}$ buffer of $\mathrm{pH} 5.5$. Cilnidipine gave one well-defined reduction peak at -0.821 potential versus $\mathrm{Ag} / \mathrm{AgCl}$ reference electrode in $\mathrm{BR}$ buffer of $\mathrm{pH} 5.5$. Reduction process was irreversible and diffusion controlled. Diffusion coefficients $\left(7.45 \times 10^{-4} \mathrm{~cm}^{2} / \mathrm{s}\right.$ and $\left.6.45 \times 10^{-4} \mathrm{~cm}^{2} / \mathrm{s}\right)$, surface coverage $\left(4.23 \times 10^{-3} \mathrm{~mol} / \mathrm{cm}^{2}\right.$ and $\left.98.01 \times 10^{-3} \mathrm{~mol} / \mathrm{cm}^{2}\right)$ and heterogeneous rate constant $\left(1.25 \times 10^{2} \mathrm{~s}^{-1}\right)$ were calculated at bare GCE respectively. Based on $\mathrm{CV}, \mathrm{CPC}$ and $\mathrm{pH}$ studies a reduction mechanism was proposed involving $6 \mathrm{H}^{+} / 6 \mathrm{e}^{-}$. The proposed square wave voltammetric method shows linearity over the concentration range $\left(4.21 \times 10^{-6}-9.71 \times 10^{-3} \mathrm{M}\right)$ The achieved limits of detection (LOD) and quantification (LOQ) are $5.44 \times 10^{-8} \mathrm{~g} / \mathrm{mL}$ and $1.52 \times 10^{-7} \mathrm{~g} / \mathrm{mL}$ respectively.
\end{abstract}

Keywords: Cilnidipine, Diffusion controlled, SW cathodic stripping voltammetry, Glassy carbon electrode

\section{Introduction}

Cilnidipine(3-O-(2-methoxyethyl) 5-O-[(E)-3-phenylprop-2-enyl $]$ 2,6-dimethyl-4-(3nitrophenyl) -1,4-dihydropyridine-3,5-dicarboxylate, Figure 1) is a novel and unique dihydropyridine calcium antagonist that possesses a slow-onset, long-lasting vasodilating effect ${ }^{1,2}$. Cilnidipine was reported to inhibit the release of $\left[{ }^{3} \mathrm{H}\right]$-noradrenaline from sympathetic nerve endings in the rat mesenteric vasculature. Recently, cilnidipine was found to have potent inhibitory action on the $N$-type as well as the $L$-type voltage-dependent calcium channels in rat dorsal root ganglion neurones ${ }^{3,4}$. Regarding the clinical advantages of cilnidipine over other dihydropyridines, we have shown that cilnidipine has less influence on heart rate and the autonomic nervous system than nifedipine retard and causes less tachycardia 
than nisoldipine in hypertensive patients. Moreover, in spontaneously hypertensive rats (SHRs), cilnidipine was reported to cause an inhibition of the pressor response induced by acute cold stress in addition to its hypotensive effect ${ }^{5}$. This finding appears to be, at least in part, explained by its unique pharmacological properties. However, no randomized studies have been carried out to investigate whether this finding applies to hypertensive patients ${ }^{6,7}$.<smiles>COCCOC(=O)C1=C(C)NC(C)=C(C(=O)OC/C=C/c2ccccc2)C1c1cccc([N+](=O)[O-])c1</smiles>

Figure 1. Chemical structure of cilnidipine

Cilnidipine decreases blood pressure and is used to treat hypertension and its comorbidities. Due to its blocking action at the $N$-type and $L$-type calcium channel, cilnidipine dilates both arterioles and venules, reducing the pressure in the capillary bed. Cilnidipine is vasoselective and has a weak direct dromotropic effect, a strong vasodepressor effect and an arrhythmia-inhibiting effect. Blood pressure control with cilnidipine treatment in Japanese post-stroke hypertensive patients (The CA-ATTEND study) the results of a large-scale prospective post-marketing surveillance study of post-stroke hypertensive patients $(\mathrm{n}=2667$, male $60.4 \%, 69.0 \pm 10.9$ years $)$ treated with cilnidipine indicate that cilnidipine was effective in treating uncontrolled blood pressure and was well tolerated in post-stroke hypertensive patients ${ }^{8,9}$. The ambulatory blood pressure control and home blood pressure (Morning and Evening) lowering by $N$-channel blocker cilnidipine (ACHIEVEONE) trial is a large-scale $(n=2319)$ clinical study on blood pressure (BP) and pulse rate (PR) in the real world with use of cilnidipine; this study revealed that cilnidipine significantly reduced BP and PR in hypertensive patients at the clinic and at home, especially with higher BP and PR in the morning. The side effects could be severe diziness, fast heartbeat, and swelling of face, lips, tongue, eyelids, hands and feet. Lesser side effects include stomach pain, diarrhea and hypotension. Peripheral edema, a common side effect from the use of amlodipine, was reduced when patients were shifted to cilnidipine ${ }^{9,10}$.

Drugs that lower blood pressure act by reducing peripheral resistance or cardiac output or both. Current pharmacological therapy for hypertension include diuretics (Thiazides, loop and $\mathrm{K}^{+}$sparing diuretics), sympatholytic drugs ( $\alpha, \beta$-antagonists), calcium channel blockers (CCBs) (nifedipine, amlodipine, cilnidipine), angiotensin-converting enzyme inhibitors (ACEI), angiotensin receptor blockers (ARB) and vasodilators. The choice of drug depends on the severity of hypertension and associated patient factors. The procedure of the autonomic function tests has been described in detail elsewhere. After resting in the sitting position in a quiet room for $30 \mathrm{~min}$, the subjects underwent a mental arithmetic test, a cold pressor test and a Valsalva manoeuvre. Edema may result in the need for dose reduction or drug withdrawal, either of which can adversely affect the efficacy ${ }^{11,12}$. A new generation of CCB, cilnidipine is an $N$-type and $L$-type CCB that also inhibits sympathomimetic activity in contrast to other DHP. Although $L$-type and $N$-type DHP CCBs are being used clinically, their specific effects on the pedal edema have not yet been elucidated. Hence, this study was taken to compare the antihypertensive 
efficacy and incidence of pedal edema with amlodipine and cilnidipine in hypertensive individuals. Mental arithmetic test: follow the continuous performance of simple arithmetic exercise for $5 \mathrm{~min}$. The patients were instructed to work as accurately as possible $\mathrm{e}^{13-16}$.

\section{Experimental}

Cilnidipine was purchased from local pharmacy under the trade name cilacar and was used without purification. A stock standard solution of bulk cilnidipine $\left(4 \times 10^{-3} \mathrm{M}\right)$ was prepared in water solvent and preserved at $4{ }^{\circ} \mathrm{C}$ until assessment. A series of BR buffer of $\mathrm{pH}$ values 3.5 to 7.0 was prepared and used as a supporting electrolyte. Deionised water was used to prepare all the solutions. The working solutions were prepared by a fix volume of stock solution and buffers.

\section{Instrumentation}

Employment for electrochemical techniques Model 1230A [SR 400] electrochemical analyzer (CHI Instrument TX, USA), with a totally automated attached to a PC with proper CHI $100 \mathrm{~W}$ version 2.3 software for total control of the experiments, treatment and data collection. A conventional three compartment cell was used for the voltammetric experiments. The working electrode was a $3 \mathrm{~mm}$ diameter glassy carbon electrode (GCE) inserted into a glass tube. The electrode was polished thoroughly with alumina and cleaned in an ultrasonic bath before each measurement. The counter electrode was a platinum wire. The reference electrode is $\mathrm{Ag} / \mathrm{AgCl}(1 \mathrm{M} \mathrm{KCl})$. A digital pH-meter (CHINO- DB-1011) fitted with a glass electrode standardized with buffers of known $\mathrm{pH}$ was used for measuring the $\mathrm{pH}$ values of the solutions.

\section{General procedure}

For total $11 \mathrm{~mL}$ solution, Britton-Robinson of $\mathrm{pH} 5.5$ and the appropriate concentration of the cilnidipine were introduced into the electrochemical cell and purged with pure deoxygenated nitrogen for 10-15 minutes under stirred conditions. These results to remove oxygen gas before measurements. Electrochemical pre-treatment was always performed in the same solution in which the measurement was subsequently carried out. The working glassy carbon electrode was polished $0.05 \mu \mathrm{m}$ aluminium oxide and sonicated for a short time to remove impurities on the electrode surface and then it was dried in an oven at $40{ }^{\circ} \mathrm{C}$. After optimization of operational parameters the cyclic and stripping voltammograms were recorded.

\section{Results and Discussion}

Electrochemical studies of cilnidipine were performed using square wave cathodic adsorptive stripping voltammetry (SW-CAdSV) and differential pulse cathodic adsorptive stripping voltammetry (DP-CAdSV). In all electrochemical methods cilnidipine gave one well defined reduction peak at $-0.7 \mathrm{~V} v s$. $\mathrm{Ag} / \mathrm{AgCl}$ reference electrode.

\section{Optimization of $p H$}

The effect of different supporting buffers (BR, citrate and acetate) on the current response of cilnidipine was studied in order to assess their impact on the monitored electro analytical signal. The best results with respect to sensitivity accompanied with sharper response were obtained with BR-buffer. Thus study was made in BR-buffer of $\mathrm{pH} 3.5$ to 7.0 at a targeted concentration of $4 \times 10^{-3} \mathrm{~g} / \mathrm{mL}$ aqueous solution of cilnidipine. Plot of peak potential (Ep) $v s$. $\mathrm{pH}$ of $4 \times 10^{-3} \mathrm{M}$ solution of cilnidipine is shown in Figure $2 \mathrm{~b}$. As depicted in Figure $2 \mathrm{a}$, the peak height attains maxima at $\mathrm{pH} 5.5$ and thereafter decreases. Therefore, $\mathrm{pH} 5.5$ was selected as the optimum $\mathrm{pH}$ for the determination of cilnidipine ${ }^{17,18}$. 

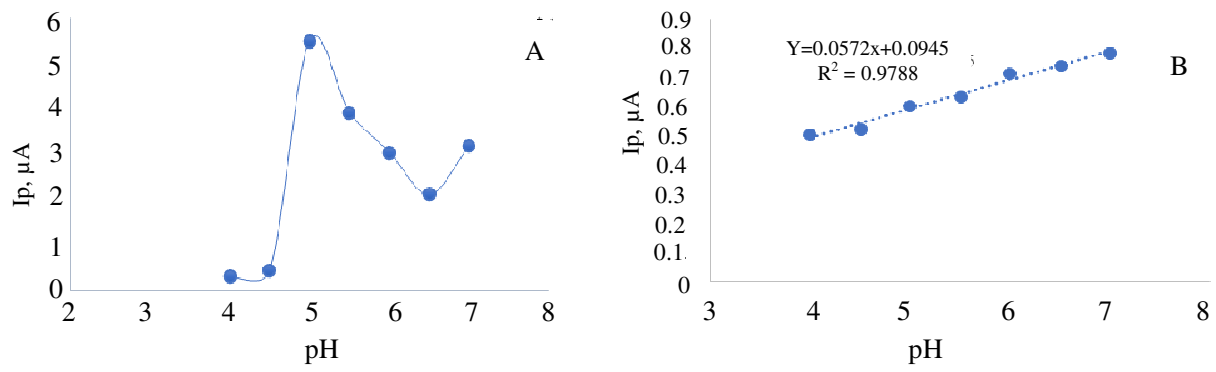

Figure 2. (a) Influence of $\mathrm{pH}$ on DPV peak current of $3.63 \times 10^{-4} \mathrm{M}$ cilnidipine in BR buffer and (b) Plot of peak potential (Ep) vs. pH of $3.63 \times 10^{-4} \mathrm{M}$

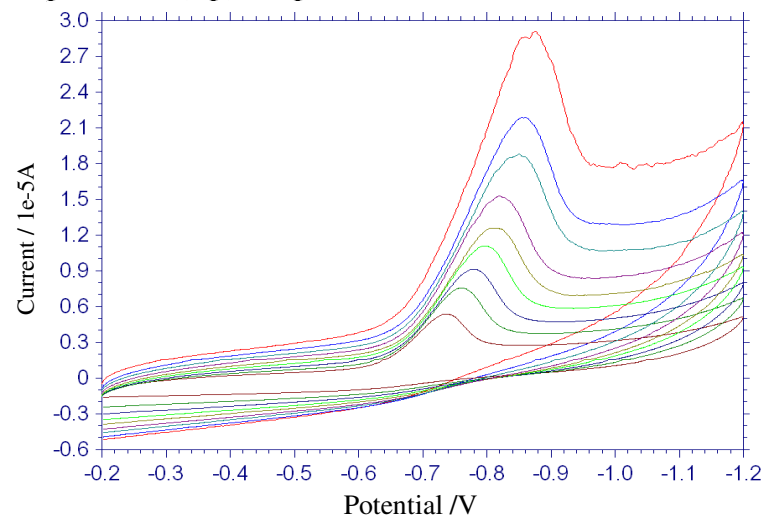

Figure 3. Cyclic voltammograms of $3.63 \times 10^{-4} \mathrm{M}$ cilnidipine in BR-buffer at different scan rates: (a) $20 \mathrm{mV} / \mathrm{s} \mathrm{(b)} 40 \mathrm{mV} / \mathrm{s} \mathrm{(c)} 60 \mathrm{mV} / \mathrm{s}$ (d) $80 \mathrm{mV} / \mathrm{s} \mathrm{(e)} 100 \mathrm{mV} / \mathrm{s}$ (f) $120 \mathrm{mV} / \mathrm{s} \mathrm{(g)} 140$ $\mathrm{mV}^{-1}$ (h) $160 \mathrm{mV} / \mathrm{s}$ (i) $180 \mathrm{mV} / \mathrm{s}$ at $\mathrm{pH} 5.5$

Furthermore, the peak potential was found to be linearly dependent on $\mathrm{pH}$ indicating about the direct involvement of proton in the reduction process and the corresponding regression equation was found to be $\mathrm{Ep}(\mathrm{V})=0.0572 \mathrm{pH}+0.0945$ with $\mathrm{r}^{2}=0.9788$.

\section{Cyclic voltammetric behaviour}

\section{Effect of scan rate}

The electrochemical behaviour of ropivacaine $\left(3.63 \times 10^{-4} \mathrm{M}\right)$ mixtures of Britton-Robinson buffers (BR-buffer) at glassy carbon electrode (GCE) with different $\mathrm{pH}$ was studied by cyclic voltammetry. The cyclic voltammogram of cilnidipine in Britton-Robinson buffers exhibits one well-defined reduction peak in the potential range of -0.2 to $-1.2 \mathrm{~V} v s$. $\mathrm{Ag} / \mathrm{AgCl}$ reference electrode at concentration $3.63 \times 10^{-4}$ and scan rates 20 to $200 \mathrm{mVs}^{-1}$ (Figure 3). The peak potential shifted towards more negative values with increasing scan rate following the Nicholson theory ${ }^{17}$. There was no peak observed in the anodic direction, suggesting the irreversible nature of the electrode process. This behaviour confirmed the irreversible character of electrode reaction. Furthermore, linear plots of peak current vs. square root of scan rate following the Ip $\alpha v^{1 / 2}$ should be obtained for a diffusion-controlled process, whereas species adsorbed on the electrode surface should result in linear plots of Ip vs. $v$.

A linear plot between peak current (Ip) and square root of scan rate $\left(v^{1 / 2}\right)$ indicate about diffusive nature of electrode process consistent with the Randles-Sevcik equation, which can be expressed as: 


$$
\mathrm{Ip}=\left(2.99 \times 10^{5}\right) \mathrm{n}\left[\alpha \mathrm{n}^{\prime}\right]^{1 / 2} \mathrm{~A} \mathrm{C}_{\mathrm{o}} \mathrm{D}_{\mathrm{o}}^{1 / 2} v^{1 / 2}
$$

Where $\mathrm{n}$ is the number of electrons exchanged in reduction, $\mathrm{n}$ ' is the number of electrons involved in the rate determining step, $\alpha$ is the charge transfer coefficient, $\mathrm{A}\left(\mathrm{cm}^{2}\right)$ is the apparent surface area of the electrode, $\mathrm{Co}(\mathrm{mol} / \mathrm{L})$ is the concentration of the electroactive species, $\operatorname{Ip}(\mu \mathrm{A})$ is the cathodic peak current, $\mathrm{D}_{\mathrm{o}}\left(\mathrm{cm}^{2} \mathrm{~s}^{-1}\right)$ is the diffusion coefficient of the electroactive species and $v\left(\mathrm{mV} \mathrm{s}^{-1}\right)$ is the scan rate.

$$
\operatorname{Ip}(\mu \mathrm{A})=1.3403 v^{1 / 2}(\mathrm{mV} / \mathrm{s})^{1 / 2}-1.8054(\mu \mathrm{A}), \mathrm{r}^{2}=0.9925
$$

The linear relationship existing between peak current (Ip) and square root of the scan rate $(v 1 / 2)$ with a slope 1.3403 confirms the diffusive nature of reduction of cilnidipine (Figure 4).
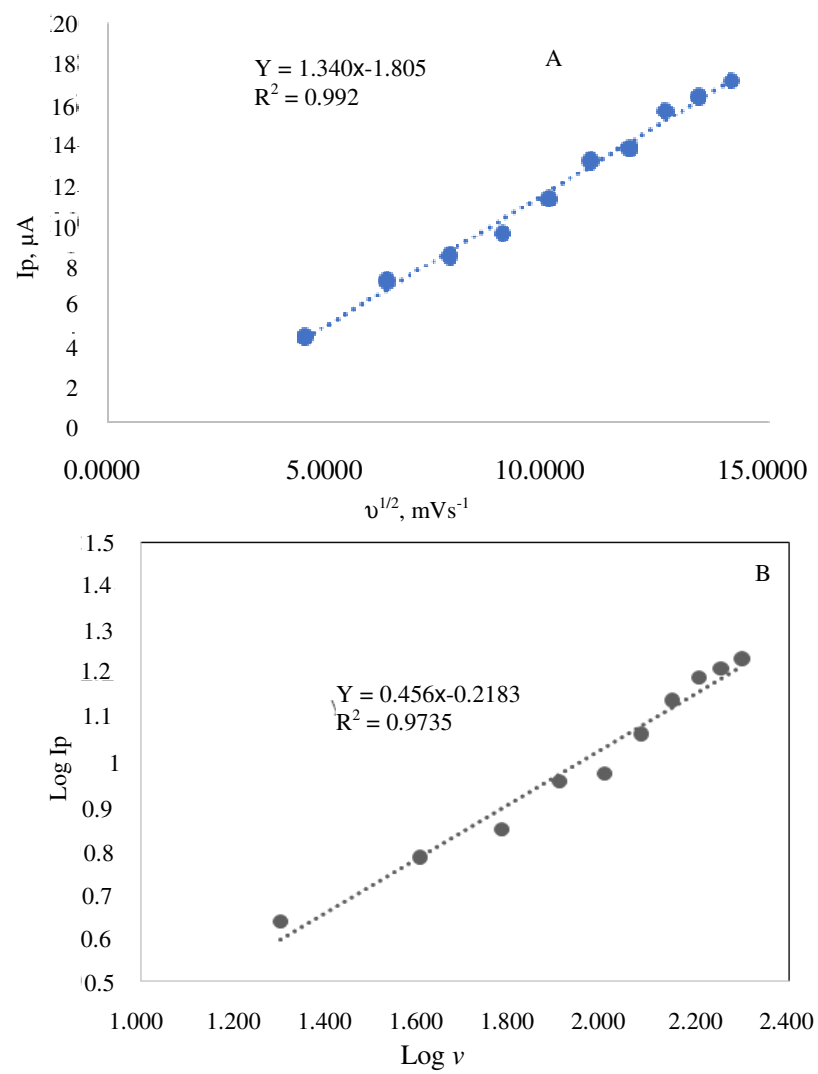

Figure 4. (A) Plot of Ip vs. $v 1 \frac{1}{2}$ for the cyclic voltammogram of $3.63 \times 10^{-4} \mathrm{M}$ cilnidipine Britton-Robinson buffer of $\mathrm{pH} 5.5$ and Figure 4(B) Influence of logarithm of peak current $\mathrm{Ip}(\mu \mathrm{A}) v s$. logarithm of scan rate $(\mathrm{mV} / \mathrm{s})$ for cyclic voltammograms of cilnidipine

The linear regression equation related to the plot of logarithm of peak current $\operatorname{Ip}(\mu \mathrm{A}) v s$. $\operatorname{logarithm}$ of scan rate $(\mathrm{mV} / \mathrm{s})$ was found to be $\log (\mathrm{Ip})=0.456 \log v-0.2183$ with $\mathrm{r}^{2}=0.9735$. Figure 4(B) shows a plot between $\log$ Ip v/s log v. Slope of this curve $(0.456 \log \mathrm{Ip} / \log \mathrm{v})$ is very close to the theoretical value of 0.5 for a pure diffusion-controlled process ${ }^{19-20}$. Moreover, intercept in the plot may be attributed to some adsorption interference present in the electrode process; due to this the rate determining step of the reduction process was termed to be diffusion controlled. 

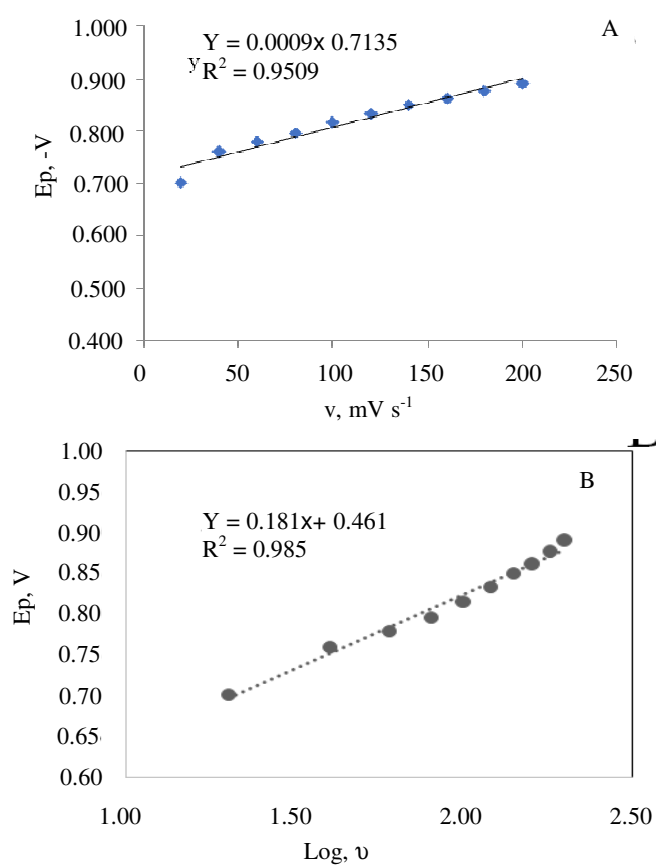

Figure 5. Plot of peak potential (Ep) versus scan rate (v) from voltammogram in Figure 2 for cilnidipine in $3.63 \times 10^{-4} \mathrm{M}$ concentration in BR-buffer of $\mathrm{pH} 5.5$ (Figure $\mathrm{B}$ ) and Plot of peak potential (Ep) versus $\log$ arithm of scan rate $(\log v)$ (Figure $A)$

\section{Kinetics of reduction of cilnidipine}

Determination of parameter [ $\left.\alpha n^{\prime}\right]$ and heterogeneous electrochemical rate constant $\left(k_{o}\right)$ According to Laviron's theory, the $\mathrm{E}_{\mathrm{p}}$ is defined by the following Eq. ${ }^{21}$ :

$$
E_{p}=E^{o}-\frac{R T}{a n^{\prime} F}\left[0.78+\operatorname{In}\left(\frac{D_{o}^{\frac{1}{2}}}{k_{s}}\right)-0.5 \operatorname{In} \frac{R T}{a n^{\prime} F}\right]-\left(\frac{R T}{2 a n^{\prime} F}\right) \operatorname{In} v
$$

Where $\alpha$ is the transfer coefficient, $v$ the scan rate, $\mathrm{n}$ the number of electron transferred, $\mathrm{k}_{\mathrm{s}}$ the standard heterogeneous rate constant of the reaction and $\mathrm{E}^{0}$ is the formal redox potential. And $\mathrm{R}, \mathrm{T}$ and $\mathrm{F}$ have their usual meanings. Thus an' was easily calculated to be 1.451 from the slope of $E_{p}$ versus $\log v$. Straight line of $E_{p} v s$. Log $v$ plot (Figure 5) is expressed by the following linear regression Eq.

$$
\mathrm{Ep}=0.1812 \log v+0.4619 \mathrm{r}^{2}=0.985
$$

The value of $\alpha$ n' was calculated by comparing slope of Eq. 2 and 3 and was found equal to 1.451 .

\section{Determination of total number of electrons}

The total number of electrons (n) involved in overall reduction process was calculated by analyzing the charge consumed by desired concentration of cilnidipine. This was accomplished by taking $5 \mathrm{~mL}$ of $4 \mathrm{mg} \mathrm{mL}^{-1}$ solution of cilnidipine in a cell and electrolysis was performed at a potential of -0.721 against $\mathrm{Ag} / \mathrm{AgCl}$ reference electrode for 5 hours. 
During the electrolysis, solutions were kept stirred and purged with nitrogen. Due to long-time electrolysis, current efficiency and completion of electrolysis were assumed to be nearly $100 \%$ and $99.98 \%$ respectively. The total number of electrons (n) involved in overall reduction process was calculated using the formula $\mathrm{Q}=\mathrm{nFN}$, where $\mathrm{Q}$ is charge in coulombs, $\mathrm{N}$ is number of moles ofCilnidipineand $\mathrm{F}$ is Faraday's constant. The value of $\mathrm{n}$ was found to be 6 for cilnidipine at bareGCE ${ }^{23-25}$.

\section{Determination of diffusion coefficient $\left(D_{o} \mathrm{~cm}^{2} / \mathrm{s}\right)$}

Electroreduction of $3.63 \times 10^{-4} \mathrm{M}$ cilnidipine at the GCE was investigated by employing cyclic voltammetry for the determination of the kinetics and mechanisms of electrode reactions. Employing cyclic voltammetry, after point-by-point background subtraction, the plot of peak current (Ip) vs. the square root of scan rate $\left(v^{1 / 2}\right)$ showed a linear relationship. According to the Randles-Sevcik equation, the diffusion coefficient of cilnidipine could then be estimated from the slope of the plot of peak current (Ip) vs. the square root of scan rate $\left(v^{1 / 2}\right)$, given by the Randles-Sevcik equation ${ }^{26-28}$.

$$
\mathrm{Ip}=\left(2.99 \times 10^{5}\right) \mathrm{n}\left[\mathrm{n}^{\prime}\right]^{1 / 2} \mathrm{~A} \mathrm{Co} \mathrm{Do}^{1 / 2} v^{1 / 2}
$$

Where $\mathrm{n}$ is the number of electrons exchanged in reduction, $\mathrm{n}$ ' is the number of electrons involved in the rate determining step of the electrode process, $\alpha$ is the charge transfer coefficient, $\mathrm{A}\left(\mathrm{cm}^{2}\right)$ is cross sectional area of the electrode, $\mathrm{Co}\left(\mathrm{mol} / \mathrm{cm}^{3}\right)$ is the concentration of the electroactive species in the bulk solution, $\operatorname{Ip}(\mathrm{A})$ is the cathodic peak current, Do $\left(\mathrm{cm}^{2} \mathrm{~s}^{-1}\right)$ is the diffusion coefficient of the electro active species being reduced and $v($ Vs- 1$)$ is the scan rate ${ }^{8}$. The value of $D_{0}\left(\mathrm{~cm}^{2} / \mathrm{s}\right)$ was found to be $7.45 \times 10^{-4} \mathrm{~cm}^{2} / \mathrm{s}$ for cilnidipine at bare $\mathrm{GCE}^{28}$.

\section{Proposed reductionmechanism}

On the basis of effect of $\mathrm{pH}$, cyclic voltammetry and controlled potential coulometry studies, it was concluded that 6 electrons and 6 protons were participating in the reduction process of Cilnidipine ${ }^{29-31}$. A reduction mechanism was proposed based on all experimental observations (Scheme 1).<smiles>COCCOC(=O)C1=C(C)NC(C)=C(C(=O)OCC=Cc2ccccc2)C1c1cccc([N+](=O)[O-])c1</smiles>

Scheme 1. Mechanism of cilnidipine

\section{Electroanalytical determination of cilnidipine}

Since voltammetric methods have cost-effectiveness high accuracy, precision, sensitivity and absence of lengthy extraction processes, therefore, they are widely used for analytical purposes. In the present paper, differential pulse cathodic adsorptive stripping voltammetric 
technique and squre wave cathodic adsorptive stripping voltammetric technique were developed for the determination of cilnidipine in pharmaceutical form at bare GCE.

\section{Optimization of parameters}

Operational parameters such as accumulation time $\left(\mathrm{t}_{\mathrm{acc}}\right)$, accumulation potential $\left(\mathrm{E}_{\mathrm{acc}}\right)$, scan increment $(\Delta S)$, peak to peak amplitude, pulse amplitude $\left(E_{\mathrm{sw}}\right)$, pulse period and pulse width etc., were optimized before recording DP-CAdS and SW-CAdSV voltammograms to get best response in terms of peak shape, peak current, peak height and peak stability. The optimized parameters are given in Table 1 .

Table 1. The optimized experimental parameters of DP-CAdSV and SW-CAdSV procedure

\begin{tabular}{cccc}
\hline $\begin{array}{c}\text { Optimized operational } \\
\text { parameters }\end{array}$ & For DP-CAdSV & $\begin{array}{c}\text { Optimized operational } \\
\text { parameters }\end{array}$ & For SW-CAdSV \\
\hline Scan increment, $\mathrm{mV}$ & 04 & Scan increment, mV & 05 \\
Pulse amplitude, $\mathrm{mV}$ & 50 & Pulse amplitude, mV & 50 \\
Deposition time (s) & 15 & Deposition time (s) & 16 \\
Deposition potential & 0.0 & Deposition potential & 0.0 \\
(V) & 0.2 & (V) & 0.3 \\
Pulse width (s) & 0.5 & Pulse width (s) & 0.4 \\
Pulse period (s) & & Pulse period (s) & \\
\hline
\end{tabular}

\section{Effect of concentration}

In order to determine the effect of concentration of cilnidipine on DP-CAdSV and SWCAdSV peak current, voltammograms of cilnidipine are recorded at bare/GCE. The linearity evaluated by linear regression analysis was calculated by least square regression method ${ }^{28-30}$. The calibration curve (Figure 6) constructed for cilnidipine is linear over the concentration $5.97 \times 10^{-6}$ to $7.45 \times 10^{-4} \mathrm{M}$ for DP-CAdSV $4.21 \times 10^{-6}$ to $9.71 \times 10^{-3} \mathrm{M}$ for SW-CAdSV method. Since the square wave cathodic adsorptive stripping voltammetry (SW-CAdSV) is more sensitive than differential pulse cathodic adsorptive stripping voltammetry (DP-CAdSV), detailed studies are carried out using differential pulse anodic adsorptive stripping voltammetry. The calibration curves were represented by the following equations:

$$
\begin{aligned}
\text { DP-CAdSV: } I_{p}(\mu A)=(253.18) C(M)+(0.558) ; & r^{2}=0.9875 ; n=6 \\
\text { SW-CAdSV: } I_{p}(\mu A)=(708.41) C(M)+(0.2754) ; & r^{2}=0.9844 ; n=6
\end{aligned}
$$

The regression plots (Figure 7) showed that there was a linear dependence of the current intensity on the concentration in both DP-CAdSV and SW-CAdSV modes over the range given in Table 2.

Table 2. Analytical parameters for voltammetric determination of cilnidipine using DPCAdSV and SW-CAdSV

\begin{tabular}{ccc}
\hline Developed methods & DP-CAdSV & SW-CAdAV \\
\hline Concentration range & $5.97 \times 10^{-6}-$ & $4.21 \times 10^{-6}-$ \\
Slope & $7.45 \times 10^{-4} \mathrm{M}$ & $9.71 \times 10^{-3} \mathrm{M}$ \\
Intercept & 253.18 & 708.41 \\
$\mathrm{R}^{2}$ & 0.558 & 0.558 \\
LOD & 0.987 & 0.9844 \\
LOQ & $5.44 \times 10^{-8} \mathrm{~g} / \mathrm{mL}$ & $7.98 \times 10^{-8} \mathrm{~g} / \mathrm{mL}$ \\
S.D & $1.52 \times 10^{-7} \mathrm{~g} / \mathrm{mL}$ & $2.17 \times 10^{-7} \mathrm{~g} / \mathrm{mL}$ \\
& $2.45 \times 10^{-4}$ & $5.47 \times 10^{-4}$ \\
\hline
\end{tabular}




\section{$L O D$ and $L O Q$}

The smallest concentration of the sample that can be detected with appreciable certainty was calculated using the Eq. ${ }^{39,40}$ :

$$
\text { LOD }=3 \mathrm{~s} / \mathrm{m}
$$

Where, $\mathrm{s}$ is the standard deviation of intercept and $m$ is the slope of the calibration curve peak current $\left(\mathrm{I}_{\mathrm{p}}\right)$ versus concentration (C) plot. LOD for the standard solution of the sample was found to be $7.98 \times 10^{-7} \mathrm{~g} / \mathrm{mL}$ and $5.44 \times 10^{-8} \mathrm{~g} / \mathrm{mL}$ using the techniques SW-AadSV and DP-AadSV respectively. The LOQ for more confident determinations was determined using the Eq.:

$$
\mathrm{LOQ}=10 \mathrm{~s} / \mathrm{m}
$$

The LOQ for the proposed method was found to be $2.17 \times 10^{-7} \mathrm{~g} / \mathrm{mL}$ and $1.52 \times 10^{-7} \mathrm{~g} / \mathrm{mL}$ using the techniques SW-AadSV and DP-AadSV respectively. The low values of LOD and LOQ proved the good sensitivity of the method.
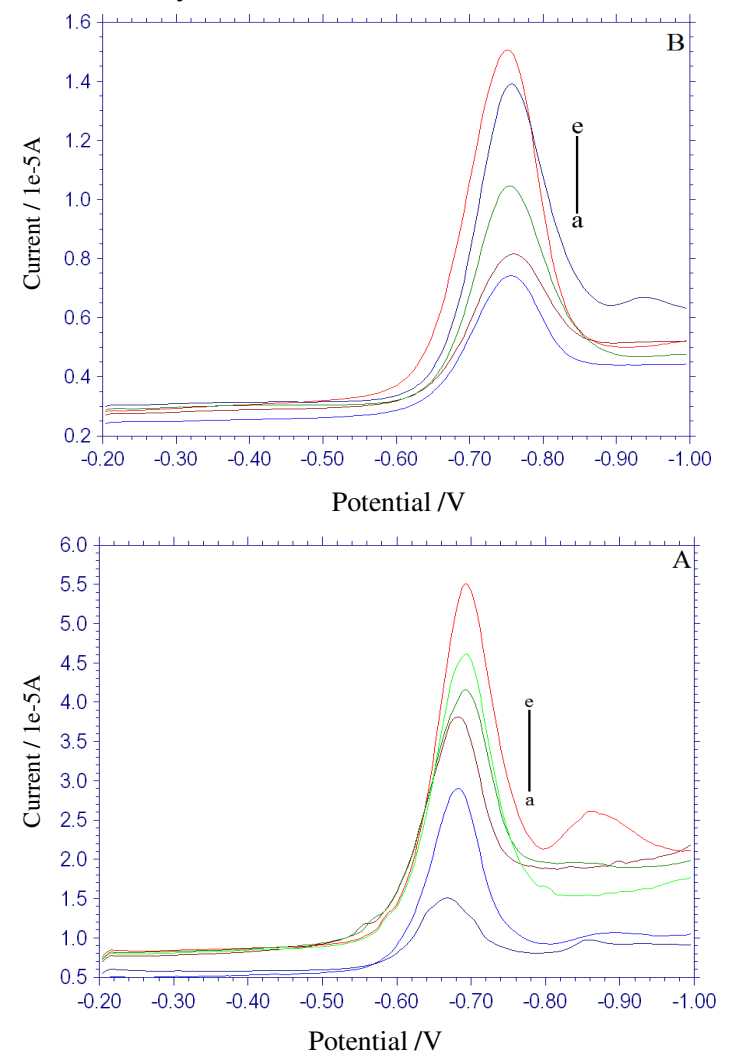

Figure 6. Figure(A) the dependence of the differential pulse cathodic adsorptive stripping voltammgram peak current(Ip) of clomipramine of different concentrations in $3.6 \times 10^{-4}$ $\mathrm{mol} / \mathrm{L}$ at bare/GCE; pH 5.5 (a) $5.97 \times 10^{-6} \mathrm{~g} / \mathrm{mL}$, (b) $7.89 \times 10^{-6} \mathrm{~g} / \mathrm{mL}$, (c) $6.47 \times 10^{-5} \mathrm{~g} / \mathrm{mL}$, (d) $2.45 \times 10^{-4} \mathrm{~g} / \mathrm{mL}$, (e) $7.45 \times 10^{-4} \mathrm{~g} / \mathrm{mL}$ and Figure (B) The dependence of the square wave cathodic adsorptive stripping voltammgram peak current (Ip) of clomipramine of different concentrations in $3.63 \times 10^{-4} \mathrm{~mol} / \mathrm{L}$ at bare $/ \mathrm{GCE}$; $\mathrm{pH} 5.5$ (a) $4.21 \times 10^{-6} \mathrm{~g} / \mathrm{mL}$, (b) $7.45 \times 10^{-5} \mathrm{~g} / \mathrm{mL}$, (c) $6.32 \times 10^{-4} \mathrm{~g} / \mathrm{mL}$, (d) $4.52 \times 10^{-3} \mathrm{~g} / \mathrm{mL}$, (e) $9.71 \times 10^{-3} \mathrm{~g} / \mathrm{mL}$ 

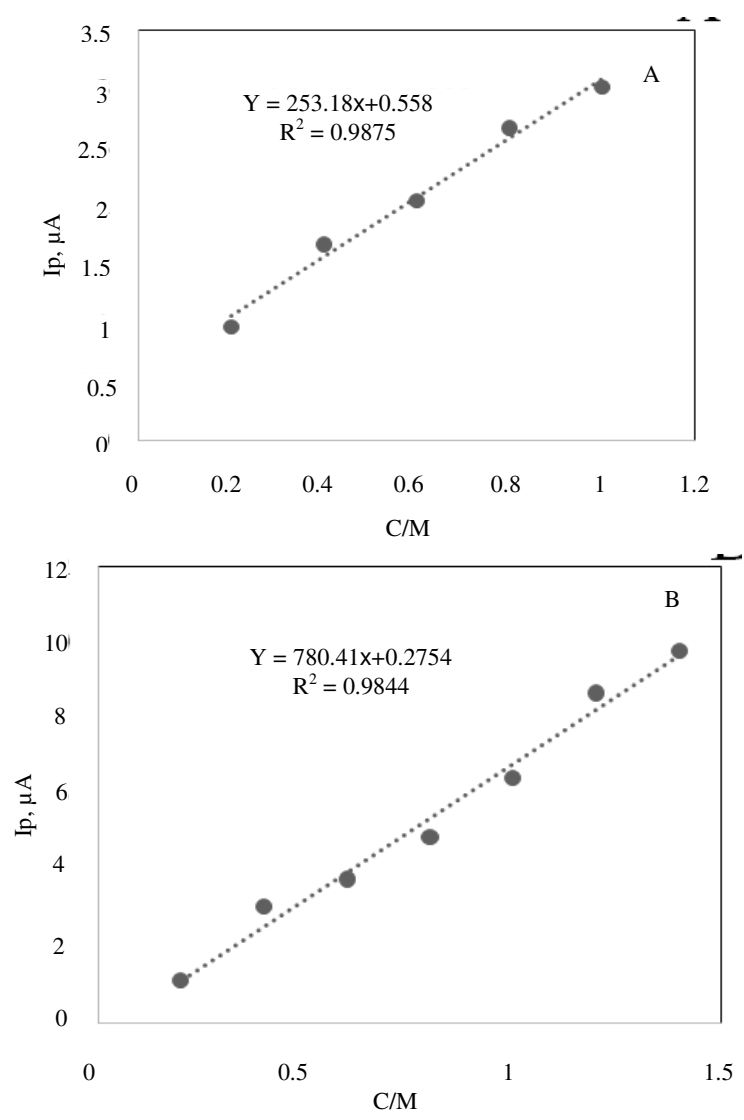

Figure 7. (A) Plot peak current $\left(\mathrm{I}_{\mathrm{p}}\right)$ versus $\mathrm{C}(\mathrm{M})$ in DP-CAdSV and Figure (B) peak current ( $\mathrm{I}_{\mathrm{p}}$ ) versus $\mathrm{C}(\mathrm{M})$ in $\mathrm{SW}-\mathrm{CAdSV}$

\section{Conclusion}

Electrochemical behaviour of cardiovascular medication cilnipipine was studied at bare glassy carbon electrode, using CV, SW-CAdSV and DP-CAdSV techniques, in pharmaceutical formulation. It was found that reduction process was irreversible, diffusioncontrolled and $\mathrm{pH}$ dependent. Furthermore, kinetic parameters such as diffusion coefficient (Do), number of electrons (n') and electron transfer coefficient $\left(\mathrm{k}_{\mathrm{s}}\right)$ were also calculated which were used to propose reduction mechanism. DP-CAdSVand SW-CAdSV method was employed for the determination of cilnipipine in apharmaceutical sample. The proposed method is direct, simple and cost-effective, requires only small amount of analyte and does not involve tedious steps such as separation, filtration, extraction, and evaporation etc., required by chromatographic methods. Under the optimum condition $(0.1 \mathrm{M} \mathrm{HCl}$ and accumulation time of $30 \mathrm{~s}$ ), the bare electrode exhibited a variety of good electrochemical characteristics including low detection limits, high sensitivity, good selectivity and favourable reproducibility.

\section{Acknowledgment}

This research is supported by the University of Rajasthan, Jaipur. 


\section{References}

1. Yoshimoto R, Dohmoto H, Yamada K and Goto A, Japan J Pharmacol., 1991, 56(2), 225-229; DOI:10.1254/jjp.56.225

2. Hosono M, Fujii S, Hiruma T, Kiyoshi W, Yutaka H, Haruo O, Yoshinobu T and Hitoshi K, Japan J Pharmacol., 1995, 69(2), 127-134; DOI:10.1254/jjp.69.127

3. Fujii S, Kameyama K, Hosono M, Hayashi Y and Kitamura K, J Pharmacol Exp Ther., 1997, 280(3), 1184-1191.

4. Minami J, Ishimitsu T, Kawano Y, Numabe A and Matsuoka H, J Cardiovasc Pharmacol., 1998 32(2), 331-336.

5. Minami J, Ishimitsu T, Higashi T, Numabe A and Matsuoka H, Hypertens Res., 1998, 21(3), 215-219; DOI:10.1291/hypres.21.215

6. Hosono M, Hiruma T, Watanabe K, Yutaka H, Haruo O, Yoshinobu T and Hitoshi K, Japan J Pharmacol., 1995, 69(2), 119-125; DOI:10.1254/jjp.69.119

7. Makino Y, Kawano Y, Okuda N, Horio T, Iwashima Y, Yamada N, Takamiya M and Takishita S, J Hypertens., 1999, 17(9), 1257-1263.

8. Huikuri H V, Pikkujamsa S M, Juhani Airaksinen K E, Markku J Ika“heimo, Asko O Rantala, Heikki Kauma, Mauno Lilja and Antero Kesa“niemi Y, Circulation, 1996, 94, 122-125; DOI:10.1161/01.CIR.94.2.122

9. Parati G, Casadei R, Groppelli A, Di Rienzo M and Mancia G, Hypertension, 1989, 13, 647-655; DOI:10.1161/01.hyp.13.6.647

10. Tochikubo O, Ikeda A, Miyajima E and Ishii M, Hypertension, 1996, 27(6), 13181324; DOI:10.1161/01.hyp.27.6.1318

11. Minami J, Kawano Y, Ishimitsu T and Takishita S, J Hypertens., 1997, 15(7), 727-735.

12. Minami J, Ishimitsu $\mathrm{T}$ and Matsuoka H, Hypertension, 1999, 33, 586-590; DOI:10.1161/01.HYP.33.1.586

13. Pagani M, Lombardi F, Guzzetti S, Rimoldi O, Furlan R, Pizzinelli P, Sandrone G, Malfatto G, Dell'Orto S and Piccaluga E, Circ Res., 1986, 59, 178-179; DOI:10.1161/01.RES.59.2.178

14. Frank S M and Raja S N, Clin Auton Res., 1994, 4(5), 257-261.

15. Takabatake T, Yamamoto Y, Nakamura S, Hashimoto N, Satoh S, Yamada Y, Ohta H and Hattori N, Eur J Clin Pharmacol., 1987, 33(3), 215-219;

DOI:10.1007/BF00637551

16. Pasanisi F, Soro S and Ferrara L A, Drugs Exp Clin Res., 1991, 17(8), 405-410.

17. Nicholson R S, Anal Chem., 1965, 37(11), 1351-1355; DOI:10.1021/ac60230a016

18. Bard A J and Faulkner L R, Electrochemical Methods: fundamentals and Applications, John Wiley and Sons. Inc., New York, 2001.

19. Armbruster D A, Tillman M D and Hubbs L M, Clin Chem., 1994, 40, 1233-1238.

20. Hay I D, Bayer M F, Kaplan M M, Klee G G, Larsen P R and Spencer C A, Clin Chem., 1991, 37(11), 2002-2008.

21. Laviron E, J Electroanal Chem., 1979, 101(1), 19-28; DOI:10.1016/S00220728(79)80075-3

22. Uslu B, Ozkan S A and Sentürk Z, Anal Chim Acta, 2005, 555, 341; DOI:10.1016/j.aca.2005.09.034

23. Tasdemir I H, Akay M A, Erk N and Kilic E, Electroanalysis, 2010, 22(17-18), 21012109; DOI:10.1002/elan.201000100

24. Bond A M, Broadening electrochemical horizons:Principal and illustration of voltammetric and related techniques, Oxford Universitry Press: New York, 2002. 
25. Fang H,Zhou J Zhou S, Dai W, Li C, Du D and Shen X, Sensors Actuators B: Chem., 2015, 210, 113-119; DOI:10.1016/j.snb.2014.12.093

26. Liu S C, Wei Y Z, Liu R Q and Fang B Z, Sci China Chem., 2013, 56(12), 17431748; DOI:10.1007/s11426-013-4945-2

27. Diculescu V C, Vivan M and Bretta A M O, Electroanalysis, 2006, 18(18), 18001807; DOI:10.1002/elan.200603591

28. Jain R and Sharma S, J Pharm Anal., 2012, 2(1), 56-61;

DOI:10.1016/j.jpha.2011.09.013

29. Kumari M and Sharma D K, J Korean Chem Soc., 2011, 55, 50; DOI:10.5012/jkcs.2011.55.1.050

30. Mourya G L, Jhankal K K, Parashar P and Sharma D K, Der Pharm Sinica., 2012, 3(6), 708-714.

31. Clinical and Laboratory Standards Institute. Protocols for Determination of Limits of Detection and Limits of Quantitation, Approved Guideline. Wayne, PA USA: CLSI; CLSI document EP17, 2004.

32. Needleman S B and Romberg R W, J Anal Toxicol., 1990, 14(1), 34-38; DOI:10.1093/jat/14.1.34

33. Lawson G M, Clin Chem., 1994, 40(7), 1218-1219.

34. Armbruster D A, Tillman M D and Hubbs L M, Clin Chem., 1994, 40(7), 1233-1238.

35. Sharma D K, Mourya G L, Jhankal K K, Jones L A and Bhargava S K, Der Pharm Letter, 2012, 4(5), 1599-1606.

36. Jhankal K K, Sharma A, Ramswaroop and Sharma D K, J Pharma Sci Res., 2015, 7(1), 10-16.

37. Sinha P, Shekhawat A and Sharma D K, Reports Electrochem., 2015, 2015(5), 21-28; DOI:10.2147/RIE.S90750 